\title{
ANTITUMOR ACTIVITY OF 1-TRIPHENYLGERMYL-4-PROPIONO- SUBSTITUTED SEMICARBAZIDES, THIOSEMICARBAZIDES AND THEIR HETEROCYCLIC DERIVATIVES
}

\author{
Fengfu Li ${ }^{1}$, Zhongbiao Zhang ${ }^{1}$ and Huan Gao*2 \\ 1 Institute of Elemento-Organic Chemistry ${ }^{2}$ Institute of Polymer Chemistry \\ Nankai University, Tianjin, 300071 , P. R. China
}

\begin{abstract}
Five organogermanium compounds with the formulae $\mathrm{Ph}_{3} \mathrm{GeCHR}^{\prime} \mathrm{CH}_{2} \mathrm{CONHNHC}(\mathrm{X}) \mathrm{NHR}^{\prime \prime}$ and<smiles>[X]C1NN2CCC1N2[R7]</smiles>

$\left(\mathrm{R}^{\prime}=\mathrm{H}, \mathrm{Ph} ; \mathrm{R}^{\prime \prime}=\mathrm{Ph}, \mathrm{p}-\mathrm{CH}_{3}-\mathrm{Ph} ; \mathrm{X}=\mathrm{S}, \mathrm{O}\right.$ ) were found to possess inhibitory effects on gastric carcinoma MGC- 803 in vitro.

Key words : germanium, organogermanium, antitumor activity

It has been reported that trialkylgermylpropanoic acids and their derivatives showed antibacterial activity $^{[1]}$ and the selectively inhibitory action on the decomposition of enzymes ${ }^{[2]}$. However, no antitumor properties of these compounds have been known in the literature. In our previous work ${ }^{[3]}$, we have reported the syntheses of some 1-triphenylgermyl-4-propiono-substituted semicarbazides, thiosemicarbazides (1) and their heterocyclic derivatives (2). In the present paper, we report the antitumor activity of these compounds.
\end{abstract}

Table 1 Effects of 1 and 2 on gastric carcinoma MGC-803

\begin{tabular}{cccc}
\hline \multirow{2}{*}{ Compounds } & \multicolumn{3}{c}{ Inhibition rate $(\%)^{\mathbf{a}}$} \\
\cline { 2 - 4 } & 1ppm $^{\mathbf{b}}$ & $\mathbf{1 0 p p m}$ & $\mathbf{1 0 0 p p m}$ \\
\hline 1a & 38.4 & 32.8 & 18.4 \\
1b & 20.0 & 28.8 & 60.8 \\
1c & 8.0 & 21.6 & 28.0 \\
2a & 28.0 & 40.0 & 48.0 \\
2b & 0.00 & 4.80 & 15.2 \\
\hline
\end{tabular}

Inhibition rate reported in this paper was tested according to reference 4 .

${ }^{b}$ Dimethyl sulfoxide was used as solvent, the same in Tables 2 and 3.

Table 2 Effects of 1 and 2 on gastric carcinoma BGC-823

\begin{tabular}{cccc}
\hline \multirow{2}{*}{ Compounds } & \multicolumn{3}{c}{ Inhibition rate (\%) } \\
\cline { 2 - 4 } & $1 \mathrm{ppm}$ & $\mathbf{1 0 p p m}$ & $\mathbf{1 0 0 p p m}$ \\
\hline 1a & -6.82 & -12.5 & -1.55 \\
1b & -4.55 & -2.27 & 68.18 \\
1c & -14.77 & -9.09 & 19.32 \\
2a & -9.09 & -4.45 & 9.09 \\
2b & -34.15 & -15.85 & -6.10 \\
\hline
\end{tabular}


Table 3 Effects of 1 and 2 on nasopharyneal darcinoma KB

\begin{tabular}{cccc}
\hline \multirow{2}{*}{ Compounds } & \multicolumn{3}{c}{ Inhibition rate(\%) } \\
\cline { 2 - 4 } & $1 \mathrm{ppm}$ & $\mathbf{1 0 p p m}$ & $\mathbf{1 0 0 p p m}$ \\
\hline 1a & -11.63 & -8.53 & -3.10 \\
1b & -7.75 & 20.93 & 56.59 \\
1c & -1.55 & 4.65 & 25.58 \\
2a & -13.18 & 7.75 & 18.60 \\
2b & -6.20 & -9.30 & -3.80 \\
\hline
\end{tabular}

$\mathrm{Ph}_{3} \mathrm{GeCHR}^{\prime} \mathrm{CH}_{2} \mathrm{C}(\mathrm{O}) \mathrm{NHNHC}(\mathrm{X}) \mathrm{NHR}^{\prime \prime}$<smiles>[X]C1NN2C([R])C1N2[R7]</smiles>

1
1a $\mathrm{R}^{\prime}=\mathrm{H}, \mathrm{X}=\mathrm{S}, \mathrm{R}^{\prime \prime}=\mathrm{p}-\mathrm{CH}_{3}-\mathrm{Ph}$
2a $\quad R^{\prime}=H, X=S, R^{\prime \prime}=p-C_{3}-P h$
1b $\mathrm{R}^{\prime}=\mathrm{Ph}, \mathrm{X}=\mathrm{S}, \mathrm{R}^{\prime \prime}=\mathrm{p}-\mathrm{CH}_{3}-\mathrm{Ph}$
2b $\quad R^{\prime}=P h, X=O, R^{\prime \prime}=P h$
1c $\mathrm{R}^{\prime}=\mathrm{Ph}, \mathrm{X}=\mathrm{O}, \mathrm{R}^{\prime \prime}=\mathrm{Ph}$

As shown in Table 1 , to some extent, compounds 1 and 2 are all effective against gastric carcinoma MGC-803 under the experimental conditions. However, no inhibitory effects were found against gastric carcinoma BGC-823 or nasopharyneal darcinoma KB under the same conditions as above (see Tables 2 and $\mathbf{3}$ ).

Acknowledgement. The authors are grateful to the State Key Laboratory of Elemento-Organic Chemistry for financial support of this project, also to Beijing Medical University for their testing of antitumor activity.

\section{REFERENCES}

1. Kakimoto, N; Yashihara, T; Akiba, M. and Takada, T. , Japanese Patent, 6200093: CA,106, $196613 \mathrm{~b}$.

2. Kakimoto, N; Katayama, T; Mori, M. and Hasato, T. , ibid, 6200092:CA, 106,196614c.

3. Chen, R. and Li, F. , Appl. Organomet. Chem. , 1995, 9, 277.

4. Denizot, F. and Lang, R. , Journal of Immulogical Method,1986, 89, 271.

Received: May 7, 1996 - Accepted: June 7, 1996 Received in revised camera-ready format: October 3, 1996 